\title{
Tüketicilerin YouTube Reklamlarına Yönelik Tutumlarının Satın Alma Davranışı Üzerindeki Etkisi ${ }^{1}$
}

- Ersin DİKER

Dr.Öğr.Üyesi Gümüşhane Üniversitesi

ersindiker@gumushane.edu.tr ORCID ID: 0000-0002-39730639

\section{ÖZET}

Bu çalı̧̧manın amacl, sosyal medya platformu olan YouTube'da yayınlanan reklamlara ilișkin tüketici tutumlarını etkileyen faktörlerin satın alma davranışı üzerine olan etkisini belirlemektir. Çalışmada, sosyal medya ve Youtube reklamcllı̆̆ııın önemi ve tüketicilerin reklamlara yönelik tutumlarn kavramsal olarak açıklandıktan sonra literatürdeki benzer çalışmalar irdelenmiştir. Türkiye'deki YouTube kullanan 18 yaş ve üstündeki tüketiciler araştırmanın evrenini oluşturmaktadır. YouTube reklamlarına yönelik tüketici tutumlarının satın alma davranışına olan etkisini tespit etmek için ise anket tekniği kullanılmıştır. Bunun için Türkiye genelinde kolayda örneklem yöntemi kullanılarak Facebook, Twitter, LinkedIn ve WhatsApp gibi sosyal platformlar yoluyla, YouTube kullanıcılarından verilerin toplandığ çevrimiçi bir anket gerçekleştirilmiştir. Araştırma bulgularına göre; tüketicilerin YouTube reklamlarına yönelik tutumlarını etkileyen faktörlerin (Eğlence, bilgi vericilik, güvenilirlik ve rahatsı edicilik) satın alma davranışını doğrudan ve anlamlı bir şekilde etkilediği görülmektedir. Tüketicilerin satın alma davranışı üzerinde en çok etkiyi sağlayan faktör ise eğlence faktörüdür. Rahatsız edicilik ile tüketicilerin satın alma davranışı arasında negatif bir ilişki bulunmaktadır. Reklamlardaki rahatsız edicilik azaldıkça satın alma davranışa yönelik olumlu tutum artacaktır.

Anahtar Sözcükler: YouTube, Sosyal Medya Reklamc1lığı, YouTube Reklamları, Tüketici Tutumları, Satın Alma Davranışı.

1 Bu çalışma, 18-19 Ekim 2018 tarihinde Mersin'de düzenlenen Uluslararası Dijital Çağda iletişim Sempozyumu'nda sunulan özet bildirinin, genişletilmiş, gözden geçirilmiş ve tam metin halidir. 


\section{The Effect of Consumers' Attitudes Towards YouTube Advertisements on Purchasing Behaviour}

\section{- Ersin DIKKER}

Assist. Prof .Dr. Gümüșhane University

ersindiker@gumushane.edu.tr ORCID ID: 0000-0002-39730639

\begin{abstract}
The purpose of this study is to find out the effect of factors influencing consumers' attitudes towards the advertisements aired on Youtube on purchasing behavior. In the study, after explaining the importance of social media and YouTube advertising, and the consumers' attitudes towards advertisements conceptually, similar studies in the literature are scrutinized. Consumers aged 18 and above using YouTube in Turkey constitute the universe of research. To find out the effect of consumers' attitudes towards YouTube advertisements on purchasing behavior survey technique is used. In this sense, using convenience sampling method through social platforms such as Facebook, Twitter, LinkedIn, and WhatsApp throughout Turkey, an online survey is applied to gather the data of YouTube users. According to the findings of the study, it is seen that the factors (entertainment, informativeness, credibility, and irritation) affecting the attitudes towards YouTube advertisements influence the purchasing behavior directly and meaningfully. The most effective factor in the consumers ' purchasing behavior is entertainment. There is a negative correlation between irritation factor and purchasing behavior. As long as the irritation in the advertisements decreases, a positive attitude towards purchasing behavior will increase.
\end{abstract}

Keywords: YouTube, Social Media Advertising, YouTube Advertisements, Consumer Attitudes, Purchasing Behaviour. 


\section{GİRIŞ}

Yaşanan teknolojik gelişmeler reklam ve reklam stratejilerinin sadece geleneksel medya ortamları ile sınırlı kalmayıp bu faaliyetlerin sosyal medya platformlarına taşınmasına yol açmıştır. Bu platformlar ile insanlar iletişim kurma, bir olay, bir durum veya marka hakkındaki bilgiye kolayca ulaşabilme ve bu bilgileri birbirleri ile anında paylaşabilmektedir. Bunun yanı sıra sosyal medya kullanımı için herhangi bir ücret ödenmemesi, insanların bu platformlarda kolaylıkla içerikler oluşturarak paylaşabilmesi ve tüketim alışkanlıklarının sosyal medya ortamlarına taşınması nedeniyle bu platformlar, reklamverenler için cazip bir yatırım alanına dönüşmüştür.

Günümüzde reklamcılık alanında önemli bir konunma sahip olan YouTube, televizyona ait olan özellikleri bünyesinde barındırmakla kalmayıp bunları kullanıcılara hızlı ve kolay bir şekilde sunmaktadır. Her gün binlerce videoların yüklendiği ve izlendiği bir ortam olan YouTube, markaların hedef kitlelerine ulaşmasında ve fark edilmesinde etkili bir sosyal medya platformudur. Tüketiciler de merak ettikleri bir ürünün reklamına, bizzat kendileri YouTube'da arayarak ulaşabilmektedirler.

Sosyal medya reklamlarına ilişkin tüketici tutumlarının, satın alma davranışı üzerindeki etkisine yönelik yapılan çalışmaların (Aydın, 2016; Can \& Kaya, 2016; Çağlıyan, Işıklar, \& Hassan, 2016; Dehghani \& Tumer, 2015; Hacıefendioğlu, 2011; İnce \& Bozyiğit, 2018; Koçer \& Koçkaya, 2016; Lee \& Hong, 2016; Lin \& Kim, 2016) daha çok sosyal medya reklamları, Facebook ve Instagram reklamları üzerinde yoğunlaştığı görülmektedir. Öte yandan YouTube reklamları üzerine yapılan araştırmalar ise (Aziza \& Astuti, 2019; Dehghani, Niaki, Ramezani, \& Sali, 2016; Karadeniz \& Kocamaz, 2019; Nabila \& Achyar, 2019; Yang, Huang, Yang, \& Yang, 2017) son yıllarda artmıştır. Dehghani, Niaki, Ramezani \& Sali yaptıkları araştırmada YouTube reklamlarının satın alma davranışına ve etkisine dair daha önce herhangi bir çalışmaya rastlamadıklarını belirtmişlerdir (2016, s. 166). Ayrıca (Hacıefendioğlu, 2011, s. 107), sosyal medya reklamlarının etkisinin araştırılması ve tüketicilerin bu platformda yer alan reklamlara yönelik tutumlarının belirlenmesinin önemine vurgu yapmaktadır. Aziza ve Astuti (2019), YouTube izleyici sayısının günden günde artmasıyla birlikte markaların tüketiciler ile iletişim kurmak için YouTube reklamlarına yöneldiklerini belirtmişlerdir. Buna rağmen literatürde YouTube reklamlarının satın alma davranışı üzerindeki etkisini inceleyen çok fazla 
çalışmaya ulaşılamamıştır. Böylece bu araştırma YouTube reklamlarının satın alma davranışını nasıl ve ne şekilde etkilediğini ortaya koyması bakımından önem arz edebilir.

YouTube'da yayınlanan reklamlara ilişkin tüketici tutumlarının satın alma davranışı üzerine olan etkisinin belirlenmesi amacını taşıyan bu çalışmada, sosyal medya reklamcılığg ve popüler video paylaşım sitesi olan YouTube incelendikten sonra, tüketici tutumu, sosyal medya reklamlarına yönelik tüketici tutumlarını etkileyen faktörler açıklanmış ve literatürdeki benzer çalışmalara değinilmiştir. Ardından, tüketicilerin YouTube'daki reklamlara ilişkin tutumlarını etkileyen faktörlerin satın alma davranışına yönelik etkisini tespit etmek için, anket tekniği kullanılarak alan araştırması yapılmıştır.

\section{SOSYAL MEDYA REKLAMCILIĞI VE YOUTUBE}

İnternet ve dijital teknolojilerin ilerlemesi ve bu teknolojilerin sağladığı ürünlere ulaşımın kolay, hızlı ve ucuz olması nedeniyle, sosyal medya uygulamaları markaların mesajlarını tüketicilere ulaştırmak için günümüzde önemli bir rol oynamaktadır. Sosyal medya kullanıcı sayısının her geçen gün artması ve belirgin hale gelmesinden dolayı, markaların bir mesajı iletmek için en etkili ve hassas iletişim ortamını belirlemeleri açısından sosyal medya araçları önemli bir çalışma alanı haline gelmiştir

Sosyal medya reklamcılığg, farklı pek çok sosyal medya platformunu içerisinde barındıran ve çoklu ortam yapısı özelliği ile oldukça geniş kitleleri kapsayan bir reklamcılık türüdür (Çakın, 2018, s. 196). Sosyal medyanın katılım, açıklık, iletişim, topluluk oluşturma ve bağl1lık (Myfield, 2007, s. 5) gibi kendine ait karakteristik özellikleri sayesinde markalar, sosyal medya platformlarını reklam iletişimlerini gerçekleştirmek için kullanmaktadırlar.

Sosyal medya reklamları sayesinde markalar; marka farkındalığını inşa etmek, tüketiciler ile erişim sağlamak, tüketici tutum ve davranışlarını incelemek, pazarlama ve reklam stratejilerine yönelik fikirler oluşturmak ve ürün veya hizmet satışlarının artmasına destek olmak gibi amaçları gerçekleştirebilmektedirler (Tuten, 2008, s. 25-26). Sosyal medyanın geniş ve hedeflenebilir erişim, hızlı içerik oluşturma, ölçümlenebilme, düşük maliyet, zaman ve mekan sınırlamasının olmaması ve çoklu çevrimiçi yapıya sahip olması gibi özellikleri sosyal medya reklamcılığının gücünü göstermektedir (Çakın, 2018, s. 196). Reklam kavramı sosyal medya ile bütünleşerek kapsamını arttırmıştır. Özellikle Instagram ve Facebook üzerinden gerçekleştirilen reklamlarla hedef kitlelere bizzat ulaşılabilmekte ve satın alma eylemi hızlı bir 
şekilde gerçekleşmektedir. Sosyal medya reklamlarının temel amacı ise tanıtım ve satış odaklı olmasıdır (Kırık, 2017, s. 19). Markalar, sosyal medya platformlarını reklam amaçlı kullanmasının yanı sıra aşağıdaki amaçları gerçekleştirebilmek için de kullanmaktadırlar (Kazançoğlu, Üstündağl1, \& Baybars, 2012, s. 161):

- Tüketiciler ile aynı zamanda iletişim kurulabilmek,

- Bütünleşik pazarlama iletişimi hedefleri doğrultsunda marka, ürün veya hizmetlerle ilgili farklı uygulamalar tasarlamak,

- Marka bilinirliğini arttırmak,

- Marka bağımlılığı yaratmak,

- Kurumsal itibara olumlu yönde katkılar sağlamak.

YouTube ise günümüzde markalar, tüketiciler, pazarlar ve tüketim ile ilgili zengin içeriklere sahip popüler video platformudur (Dehghani, Niaki, Ramezani, \& Sali, 2016, s. 165). YouTube, kullanıcıların video yüklemelerini sağlayan ve çevrimiçi olarak erişebilecekleri bir video paylaşım sitesidir. 2005 yılında kurulan YouTube, Google tarafından 2006 yılında satın alınmıştır. YouTube, dünyanın en popüler video paylaşım sitesi olma özelliğine sahiptir (Özkaşıkçı, 2012, s. 104). Tüm dünyada sosyal medya kullanım verilerini raporlayan We Are Social'ın 2020 Türkiye raporuna göre YouTube Türkiye'deki sosyal medya platformları arasında en çok kullanılan uygulamadır (Nurluoğlu, 2020). Türkiye ve dünyanın internet ve sosyal medya kullanım alışkanlıklarını sunan ve önemli bir kaynak olarak görülen Global Web Index'e göre, Türkiye'deki 16-64 yaş aralığındaki internet kullanıcılarının \%92'si YouTube'u aktif olarak kullanmaktadırlar (Yüksel, 2020, s. 37). Böylece sosyal medya platformlarının yükselişi, içerik reklamcılığının yaygınlaşması ve gelişmesi nedeniyle, marka iletişimi ve pazarlaması bağlamında çevrimiçi reklamcılık platformu olan YouTube reklamverenlerin de dikkatini çekmeyi başarmıştır.

\section{TÜKETİCILERIN REKLAMLARA YÖNELIKK TUTUMLARI}

Bireyin herhangi bir şey ile ilgili duygu, düşünce ve davranışlarını oluşturan eğilimler tüketici tutumunu meydana getirmektedir (Elden, Ulukök, \& Yeygel, Şimdi reklamlar, 2005, s. 224). Tüketici sahip olduğu tutum ile nesneler ve düşünceleri zihninde olumlu ya da olumsuz olarak değerlendirip gruplandırmaktadır (Yükselen, 2016, s. 123). Bireylerin oluşturdukları tutumlar onların satın alma kararlarına doğrudan etkileri olabilir. Tüketicilerin vermiş oldukları 
satın alma kararları sahip oldukları tutumun pekiştirilmesini veya değiştirilmesini etkileyebilir (Odabaşı \& Barış, 2002, s. 158).

Bir reklamın etkililiğini anlamak için tüketicilerin (izleyicilerin) tutumları önemli bir faktördür. Lutz (1985), reklama yönelik tutumu, "Belirli bir reklam uyarısına olumlu veya olumsuz bir şekilde yanıt verme eğilimi" olarak tanımlamaktadır (MacKenzie, Lutz, \& Belch, 1986). ). Reklama karşı tutum, tüketicinin reklama karşı olumlu ya da olumsuz tepki içeren bir eğilimidir. Reklama karşı oluşan tutumlar satın alma davranışını da etkilemektedir. Reklamın yaratacağı olumlu duygu markaya karşı tutum ve ürünün satın alınmasına yönelik tutumla ilişkili olmaktadır (Çalıkuşu, 2009, s. 205)

Tüketicinin reklama karşı tutumu ve tüketicinin bir reklamdan yararlı bilgiler alıp almadığ1 ve reklamı beğenip beğenmediği reklamın etkili olup olmamasının çok iyi bir göstergesidir (Kotler, 2000, s. 115). Tüketicilerin reklamlara yönelik olumlu tutum geliştirmeleri, reklamın bilgilendirici ve haberdar edici gibi kendine ait özelliklerinden dolayı kaynaklanabilir (Onay, 2012, s. 53).

İnternet reklamlarına yönelik tutumlar bağlamında literatürde önemli ve öncü çalışmalardan biri olarak kabul edilen Ducofee'un reklam değeri teorisine dayandırarak yapmış olduğu çalışmadan buradan bahsetmek yerinde olacaktır. Ducofee; eğlence, bilgi vericilik ve rahatsız ediciliğin internet (web) reklamlarına yönelik tutumları etkileyen faktörler olduğunu belirtmiştir. Reklamların bilgi vericilik ve eğlence içerikli olması reklama verilen değerin önemli bir göstergesidir. Öte yandan, rahatsız edici olarak algınanan unsurların reklamlarda yer alması reklamlara yönelik olumsuz etkiler meydana getirmektedir (Ducoffe, 1996).

Ducoffe'un (1996) internet reklamcılığına karşı tüketici tutumlarını etkileyen faktörleri belirlediği modele, Brackett ve Car (2001) yapmış oldukları çalışmaya güvenilirlik ve demografik değişkenini de ekleyerek modelin açıklama gücünü arttırmışlarlardır. Güvenilirliğin hem reklam değeri hem de reklama yönelik tutumla doğrudan ilişkisi olduğunu, üniversite mezunu, yaş ve cinsiyet gibi demografik değişkenlerin ise sadece reklamlara yönelik tutumları etkilediğini belirtmişlerdir.

İşletmeler ve markaların sosyal medya platformlarında yayınladıkları reklamlar tüketicilerde bir algı oluşturmaktadır. Bu algının olumlu olması sosyal medya reklamlarının başarılı olduğu anlamına gelmektedir (Kayapınar, Kayapınar, \& Tan, 2017). Tüketicilerin 
sosyal medya reklamlarına yönelik tutumları üzerine yapılan çalışmalarda da (Aydın, 2016; Haida \& Rahim, 2015; Yoldaş \& Özaydın, 2017) tüketici tutumlarına etki eden faktörlerin güvenilirlik, eğlence, bilgi vericilik ve rahatsız edicilik olduğu görülmüştür. Tüketicilerin sosyal medya reklamlarına yönelik tutumlarını etkileyen faktörler kısaca şu şekilde açıklanabilir:

Güvenilirlik: Tüketicilerin bir reklamdaki markanın dürüst ve güvenilir olduğunu hissetmesi durumu olarak tanımlanmaktır. Reklam güvenilirliği tüketicinin genel olarak reklamlara olan güveni ve gerçeği algılamasıdır (MacKenzie \& Lutz, 1989, s. 51). Brackett ve Carr (2001) ve MacKenzie ve Lutz (1989) yaptıkları araştırmalarda reklamdaki güvenilirlik unsurunun, reklamın değeri ve tüketici tutumu üzerinde etkisinin olduğu sonucuna ulaşmışlardır.

Eğlence: Sosyal medya çoğu zaman tüketiciler tarafından eğlenceli bir mecra olarak görüldüğü için, reklam içeriklerinin de eğlenceli olması beklenir (Kayapınar, Kayapınar, \& Tan, 2017, s. 475). Reklam içeriklerinde yer alan mizah, oyun, müzik vb. özellikler tüketcilerin dikkatini çekerek reklam mesajının başarılı olmasında etkilidir (Sabuncuoğlu \& Gülay, 2016, s. 118). Eğlence motivasyonu yüksek olan tüketiciler, algılanan eğlence faktörü nedeniyle sosyal medya reklamlarına yönelik olumlu tutum sergileyebilmektedirler (Çelebi, 2015). Tüketicilerin eğlence içerikli sosyal medya reklamlarına karşı olumlu bir tutum sergilediklerinde, reklamları daha fazla hatırladıkları ve reklamdaki ürün ve hizmetlere yönelik satın alma isteği oluştuğu söylenebilir (Kayapınar, Kayapınar, \& Tan, 2017, s. 476).

Bilgi vericilik: Reklamın bilgi vericilik fonksiyonu, ürünlerin kullanım biçimlerinin gösterilmesi, fiyatının belirtilmesi, ürünün nasıl çalıştığının anlatılması ve ürünle ilgili servislerin tanıtımı gibi konuları içermektedir (Elden, 2009, s. 178). Reklamlar tüketicileri ürün ve ürün alternatifleri hakkında bilgilendirmektir. Aynı zamanda tüketiciler reklamlardaki bilgilendirmeden yükssek bir memnuniyet duyduklarında da satın almaya yönelik davranışta bulunmaktadırlar (Ducoffe, 1996, s. 22). Reklamlarda yer alan ürün veya hizmetin içeriğgi, özelliği, fiyatı, kullanım biçimi ve tüketiciye sunduğu faydaların net, açık ve ikna edilebilir bir şekilde anlatılması tüketicide reklama ve satın alma davranışına yönelik olumlu bir tutum oluşturabilir. Reklamdaki bilginin doğruluğu, güncelliği ve fayda sunması tüketicilerin reklamlara yönelik tutumlarını etkileyebilmektedir (Bauer, Barnes, Reichardt, \& Neumann, 2005). 
Rahatsız edicilik: Reklamın bir engel ve sinir bozucu olarak görülmesi ve reklamlarda aşırı derecede manipüle edici tekniklerin yer alması, tüketicilerin bu reklamları istenmeyen ve rahatsız edici bir etki olarak algılayacakları anlamına gelmektedir. Reklamlardaki rahatsızlık, reklamların tüketicileri ne ölçüde rahatsız ettiği ve olumsuz izlenimler uyandırdığı ile ilgilidir (Ducoffe, 1996, s. 23; Nabila \& Achyar, 2019, s. 93). YouTube reklamlarında izlenilen videolar içinde atlanamayan reklamların yer alması, reklam izlemeden videoya izlemeye devam edilememesi ve çok yoğun reklamla karşılaşılması tüketiciler tarafından rahatsız edici bir unsur olarak görülebilmektedir.

Demografik: Reklamlara yönelik tutumlara etki eden yukarıdaki faktörlerin yanı sıra, demografik değişkenlerin de tutumları etkileyebileceğini ifade eden Brackett ve Carr (2001), yapılacak araştırmalarda demografik değişkenlerin de incelenmesi gerektiğini vurgulamışlardır. Yaş ve cinsiyet gibi demografik değişkenler, reklama yönelik tutumları etkileyebilmektedir.

Satın Alma Davranışı: Tüketicilerin ürün ve hizmetlere daha hızlı bir şekilde ulaşmaları, sosyal medya platformları sayesinde çevreleriyle fikir alış verişi yapmaları, işletmelerin sosyal medya üzerinde tüketicilerden geri bildirim almaları ve tüketicilerle iletişime geçmeleri işletmelerin ve markaların sosyal medya platformlarını daha çok kullanmalarına neden olmuştur (Kayapınar, Kayapınar, \& Tan, 2017, s. 473-474). Aynı zamanda, tüketiciler bir ürün satın almadan önce sosyal medyada araştırma yapmakta, ürünün özelliklerini ve kullanıcı yorumlarını da dikkatlice incelemektedirler. Böylece sosyal medya tüketicilerin satın alma davranışlarına yön veren bir mecra haline gelmiştir (İnce \& Bozyiğit, 2018, s. 42). Torun (2017), tüketicilerin satın alma davranışında internetin ve sosyal medyanın etkisi üzerine yapmış olduğu araştırmada, tüketicilerin satın alma sürecinde sosyal medyadan etkilendikleri ve sosyal medyanın satın alma davranışları üzerinde etkili olduğu sonucuna ulaşmıştır.

\section{KONU ILE İLGILI YAPILAN ÇALIŞMALAR}

YouTube reklamcılığının genç tüketiciler üzerindeki etkisini belirlemek amacıyla yapılan bir araştırmada (Dehghani, Niaki, Ramezani, \& Sali, 2016), 315 üniversite öğrencisine anket uygulanmış ve araştırmaya katılanların tutumları ile eğlenceli, bilgi verici ve kişiselleştirme içerikli reklamlar arasında olumlu yönde bir ilişki olduğu sonucuna ulaşılmıştır. Bunun yanı sıra rahatsız edicilik faktörünün, YouTube reklamlarına yönelik tutumda olumsuz 
bir etkiye sahip olduğu görülmüştür. Araştırmada YouTube reklamlarının tüketicilerin satın alma niyeti üzerinde önemli etkileri olduğu sonucuna da ulaşılmıştır.

Yang ve diğerlerinin (2017) YouTube reklamlarına ilişkin tüketici tutumlarını inceledikleri çalışmada; tüketici tutumlarını etkileyen eğlence, bilgi vericilik, güvenilirlik ve rahatsız edicilik boyutlarının tüketicilerin satın alma davranışlarına etkisi olduğu sonucuna ulaşmışlardır. Özellikle eğlence faktörünün diğer faktörlere göre açıklayıcı etki düzeyinin daha yüksek olduğu görülmüştür. Rahatsız edicilik faktörünün de negatif yönde bir etkisi olduğu bu araştırmada ortaya konulmuştur.

Aydın'ın (2016) sosyal medya ve mobil reklamlara yönelik tüketici tutumlarını belirmeye yönelik yapmış olduğu çalışmada tutumların öncülleri arasında, eğlencenin tutum üzerinde en güçlü etkiye sahip olduğu görülürken, güvenilirliğin tutumları etkileyen en önemli ikinci faktör olarak ortaya çıktığı görülmüştür.

Haida ve Rahim (2015) yapmış oldukları çalışmada sosyal medya reklamlarının uygulanması ve kullanılması açısından ilk önce eğlendirici olmasından ziyade bilgilendirici olmaya odaklanılması gerektiğini, kullanıcıları rahatsız eden uygulamalara yer verilmemesi gerektiğini ifade etmişlerdir.

Can ve Kaya (2016) sosyal medya reklamlarına yönelik tüketici tutumlarının satın alma niyetine etkisini kullanımlar ve doyumlar yaklaşımı bağlamında ölçmeyi amaçladıkları çalışmada, reklama yönelik tutumun satın alma niyetini etkilediğini bulmuşlardır. Ayrıca bu çalışmada sosyal medya kullanım motivasyonlarının reklama yönelik tutumları etkilediği de belirlenmiştir.

Yoldaş ve Özaydın'ın (2017) sosyal medya reklamlarının tüketici satın alma niyeti üzerindeki etkisini tespit etmek için yapmış oldukları çalışmada ise, bilgi vericilik, eğlence ve güvenilirlik faktörleri satın alma niyetini pozitif yönde etkilerken, rahatsız edicilik faktörünün ise negatif yönde etkilediği görülmektedir. Benzer bir çalışmada da bilgi vericilik, eğlence ve ekonomiye yararlılık boyutlarının tüketicilerin satın alma niyetini pozitif yönde etkilediği, güvenilirlik faktörünün ise tutum üzerinde herhangi bir etkisinin olmadığg sonucuna ulaşılmıştır (Akkaya, Akyol, \& Şimşek, 2017).

Nabila ve Achyar (2019) yapmış oldukları araştırmada eğlence ve güvenilirlik faktörlerinin satın alma niyetini ve reklama yönelik değeri olumlu yönde etkilediğini ortaya 
koymuşlardır. Ayrıca bu çalışmada, rahatsız edicilik unsurunun YouTube reklamlarına yönelik olumsuz bir tutum olduğu, bilgi vericiliğin ise YouTube'daki reklam değeri üzerinde hiçbir etkisinin olmadığı ortaya konulmuştur.

YouTube reklamlarının genç tüketicilerin satın alma niyeti üzerindeki etkilerine yönelik başka bir çalışmanın (Aziza \& Astuti, 2019) sonuçları göstermektedir ki, YouTube reklamlarının eğlenceli ve bilgilendirici olmasının reklam değeri üzerinde olumlu bir etkisi bulunmaktadır. Diğer bir ifade ile YouTube reklamları ne kadar eğlenceli ve bilgilendirici olursa, reklama verilen değer de o kadar yüksek olmaktadır. Reklamlara yönelik olumsuz tutumlara yol açacak unsurların (örneğin rahatsız ediciliğin) azaltılması reklamlara yönelik olumlu tutumların artmasına neden olabilir. Böylece reklamlara yönelik olumlu tutumların artması, markanın farkındalığını arttırabilecek ve tüketicinin satın alma niyetine de yol açabilecektir.

Karadeniz ve Kocamaz (2019) Facebook, Youtube ve Instagram reklamlarının tüketicilerin satın alma davranışlarına etkisinin araştırılmasına yönelik yapmış oldukları çalışmada, bilgi vericilik, hedonik motivasyon, güvenilirlik ve ekonomik faydanın satın alma davranışı üzerinde anlamlı etkileri olduğunu tespit etmişlerdir. Araştırmada bilgi vericiliğin satın alma davranışını en çok etkileyen değişken olduğu görülmüştür.

\section{ARAŞTIRMANIN YÖNTEMI}

Bu çalışmanın temel amacı, reklam mecrası olarak kullanılan YouTube'da yayınlanan reklamlara ilişkin tüketici tutumlarına etki eden faktörlerin satın alma davranışı üzerindeki etkisini ve ilişkisini belirlemektir. Bu bağlamda Türkiye'deki YouTube kullanan 18 yaş ve üstündeki tüketiciler araştırmanın evreninin oluşturmaktadır. Araştırmanın örneklemi ise, kolayda örnekleme yöntemi ile belirlenen 546 YouTube kullanıcısıdır. Araştırma öncesi, anket formundaki ifadelerin anlaşılırlığını tespit etmek, anlaşılmayan veya açık olmayan ifadelerin ise anket formundan çıkarılması amacıyla 50 katılımcıya bir ön test uygulanmıştır. Ön test sonrası son hali verilen çevrimiçi anket formu 25 Temmuz-9 Ağustos 2018 tarihleri arasında sosyal medya platformlarından paylaşılarak YouTube kullanıcılarının ankete katılımı istenmiştir. Çevrimiçi anket formunda eksik ya da hatalı yanıt verildiğinde, anket tamamlanamayacağından dolayı arzulanan örneklem sayısına ulaşılana kadar anket linki açık tutulmuştur. Böylece ankete katılanların eksik ya da hatalı yanıt vermesi engellenmiştir. 
Hazırlanan çevrimiçi anket formu iki bölümden oluşmaktadır. Birinci bölümde Ducoffe (1996) ve Brackett ve Carr'ın (2001) çalışmalarından referans alarak Wang, Sun, Lei ve Toncar (2009) ve Yang ve diğerlerinin (2017) kullanmış olduğu "Reklamlara yönelik tutumlara etki eden faktörler" (1......12. ifadeler) ve Kazançoğlu ve diğerlerinin (2012) çalışmasında kullandıkları "Satın alma davranışı" (13....17. ifadeler) değişkenlerini içeren toplam 17 maddeden oluşan ölçek kullanılmıştır. Kazançoğlu ve diğerlerinin (2012) çalışmasında kullandıkları "Satın alma davranışı”" boyutundaki ifadeler bu çalışmanın kapsamı ve içeriği ile uyumlu olarak görüldüğünden ve ilgili çalışmada bu faktörün Cronbach Alfa katsayısı $\alpha=, 918$ (yüksek düzeyde güvenilir) olduğundan tercih edilmiştir. Ölçekteki ifadeler YouTube reklamlarını yönelik olarak yeniden düzenlenmiştir. Kazançoğlu ve diğerlerinin (2012) çalışmasında kullanılan ölçek, Aktaş ve Aktan'ın (2014) yapmış oldukları " Sosyal medya reklamları ve tüketici tutumları: Bir reklam mecrası olarak Facebook" başlıklı çalışma da kullanılmıştır.

Bu ölçekte yer alan 17 madde beşli likert ifadelerinden oluşmaktadır. Anket formunun ikinci bölümünde ise katılımcıların cinsiyet, yaş, eğitim ve gelir durumunu tespitine yönelik demografik özelliklere ait sorular ile internet ve YouTube kulanım sıklığına yönelik sorular yer almaktadir.

Araştırmada elde edilen verilerin analizi için IBM SPSS 23.0 programı kullanılmıştır. Araştırmada ankete katılanların cinsiyet, yaş, günlük internet kullanım sıklığı, günlük YouTube kullanım sıklığı, eğitim durumu ve aylık gelirlerini tespit etmek için betimsel istatistik analizleri (frekans yüzde) yapılmıştır. Aynı zamanda ankete katılanların YouTube reklamlarına yönelik tutumlarını etkileyen faktörleri tespit etmek ve bu faktörlerin satın alma davranışı üzerindeki etkisin ve ilişkisini belirlemek amacıyla Faktör analizi, Bağımsız Örneklem T-Testi, Pearson Korelasyon Katsayısı ve Çoklu Regresyon Analizi kullanılmıştır

\subsection{Araştırmanın Sınırlılıkları}

$\mathrm{Bu}$ araştırmanın türü zamanı ele alış bakımında kesitsel bir araştırmadır. Araştırmada elde edilen veriler, zaman, maliyet ve örnekleme ulaşma zorluğundan dolayı iki haftalık zaman dilimi içerisinde elde edilmiştir. Zaman bakımından kesitsel bir araştırma olan bu çalışmada elde edilen sonuçların, genellenebilirliğinin ve dışsal geçerliliğinin sınırlı olacağı söylenebilir. 


\subsection{Araştırmanın Hipotezleri}

Cinsiyet ve gelir durumu reklamlara yönelik tutumlara ve satın alma davranışına etki edebilen önemli bir değişkendir. Bu bağlamda araştırmada, araştırmaya katılanların cinsiyet ve gelir durumları ile YouTube reklamlarına yönelik tutumları etkileyen faktörler arasındaki ilişki de analiz edilmiştir. YouTube reklamlarına yönelik tutumların tüketicilerin satın alma davranışını nasıl etkilediğini ve bu değişkenler arasındaki ilişkileri ortaya koyabilmek amacıyla ilgili literatür (Brackett \& Carr, 2001; Dehghani, Niaki, Ramezani, \& Sali, 2016; Ducoffe, 1996; Wang, Sun, Lei, \& Toncar, 2009; Yang, Huang, Yang, \& Yang, 2017; Yoldaş \& Özaydın, 2017) çerçevesinde aşağıdaki hipotezler oluşturulmuştur.

H1: YouTube reklamlarının eğlence boyutu, tüketicilerin satın alma davranışını doğrudan ve anlamlı bir şekilde etkilemektedir.

$\mathbf{H}_{2}$ : YouTube reklamlarının bilgi vericilik boyutu, tüketicilerin satın alma davranışını doğrudan ve anlamlı bir şekilde etkilemektedir.

H3: YouTube reklamlarının güvenilirlik boyutu, tüketicilerin satın alma davranışını doğrudan ve anlamlı bir şekilde etkilemektedir.

H4: YouTube reklamlarının rahatsız edicilik boyutu, tüketicilerin satın alma davranışını doğrudan ve anlamlı bir şekilde etkilemektedir.

H5: Gelir değişkeni ile YouTube reklamlarına yönelik tutumları etkileyen faktörler arasında anlamlı bir ilişski vardır.

H6: Cinsiyet değişkeni ile YouTube reklamlarına yönelik tutumları etkileyen faktörler arasında anlamlı bir farklılık vardır.

\subsection{Bulgular}

Araştırmada verilerin normal dağılım gösterip göstermediğini tespit etmek amacıyla basıklık (kurtosis) ve çarpıklık (skewness) katsayıları incelenmiştir. Normal dağılım için basıklık ve çarpıklık değerlerinin -1 ve +1 aralığında olması beklenir (Tabachnick \& Fidell, 2007). $\mathrm{Bu}$ araştırmada elde edilen verilerin basıklık ve çarpıklık katsayılarının -1 ve +1 aralığında olduğu görülmüş̧ür. (Tablo-1) Böylece veriler normal dağılım gösterdiği için değişkenler arasındaki ilişkileri tespit etmek amacıyla parametrik analizler kullanılmıştır. 
Tablo-1 Çarpıklık ve basılklık değerleri

\begin{tabular}{|l|l|r|r|}
\hline & N & Çarpııklık & Basılklık \\
\hline Satın Alma Davranışı & 546 &, 459 &,- 675 \\
Eğlence & 546 &, 361 &,- 638 \\
Bilgi vericilik & 546 &,- 555 &,- 476 \\
Güvenilirlik & 546 &,- 040 &,- 686 \\
Rahatsız Edicilik & 546 &,- 689 &,- 559 \\
\hline
\end{tabular}

Tablo-2 Sosyo- demografik özellikler ( $\mathrm{n}=546)$

\begin{tabular}{|c|c|c|c|}
\hline & & Sayı & $\begin{array}{l}\text { Yüzde } \\
(\%)\end{array}$ \\
\hline \multirow[t]{2}{*}{ Cinsiyet } & Kadın & 275 & 50,4 \\
\hline & Erkek & 271 & 49,6 \\
\hline \multirow[t]{4}{*}{ Yaş } & $18-24$ & 233 & 42,6 \\
\hline & $25-31$ & 169 & 31,0 \\
\hline & $32-38$ & 90 & 16,5 \\
\hline & 39 yaș ve üstü & 54 & 9,9 \\
\hline \multirow[t]{6}{*}{ Gelir } & 1000 TL alt1 & 174 & 31,9 \\
\hline & $1001-1500 \mathrm{TL}$ & 23 & 4,2 \\
\hline & $1501-2000 \mathrm{TL}$ & 89 & 16,3 \\
\hline & 2001-2500 TL & 29 & 5,3 \\
\hline & $2501-3000 \mathrm{TL}$ & 34 & 6,2 \\
\hline & 3001 TL ve üstü & 197 & 36,1 \\
\hline \multirow[t]{6}{*}{ Ĕ̆itim } & İlkokul & 4 &, 7 \\
\hline & Ortaokul & 2 & ,4 \\
\hline & Lise & 47 & 8,6 \\
\hline & Ön Lisans & 38 & 7,0 \\
\hline & Lisans & 311 & 57,0 \\
\hline & Lisansüstü & 144 & 26,4 \\
\hline \multirow{4}{*}{$\begin{array}{l}\text { Güinlük İnternet } \\
\text { Kullanımı }\end{array}$} & 2 Saatten az & 44 & 8,1 \\
\hline & 2-4 Saat & 159 & 29,1 \\
\hline & 5-7 Saat & 178 & 32,6 \\
\hline & 7 Saatten fazla & 165 & 30,2 \\
\hline \multirow{4}{*}{$\begin{array}{l}\text { Günlüik YouTube } \\
\text { Kullanımı }\end{array}$} & 2 Saatten az & 365 & 66,8 \\
\hline & 2-4 Saat & 146 & 26,7 \\
\hline & 5-7 Saat & 19 & 3,5 \\
\hline & 7 Saatten fazla & 16 & 2,9 \\
\hline
\end{tabular}

Araştırmaya katılan 546 YouTube kullanıcısının \% 50,4'ü kadın, \%49,6'sı erkektir. \%42,6'sı 18-24 yaş, \%31'i 25-31 yaş, \%16,5'i 32-38 yaş ve \%9,9'u 39 yaş grubundadır. Katılımcıların \%36,1'i 3001 TL ve üstü, \%31,9’u 1000 TL ve altı, \%16,3’ü 1501-2000 TL, 
\%6,2'si 2501-3000 TL ve \%5,3'ü 2001-2500 TL aralığında gelire sahiptir. Araştırmaya katılanların eğitim durumu dağılımlarına bakıldığında, \%57'si Lisans, \%26,4'ü lisansüstü, \%8,6'sı lise, \%7'si ön lisans mezunudur. İlkokul ve ortaokul mezunu katılımcıların oranı ise \%1'in altında kalarak çok düşük bir orandadır. Katılımcıların günlük internet kullanım durumları incelendiğinde $\% 32,6$ 's1 5-7 saat, \%30,2'si 7 saatten fazla, $\% 29,1$ 'i 2-4 saat ve \%8,1'i ise 2 saatten az internette vakit geçirdikleri görülmektedir. Öte yandan katılımcıların günlük YouTube kullanımına bakıldığında, \%66,8'i 2 saatten az, \%26,7'si 2-4 saat, \%3,5'i 5-7 saat ve \%2,9’u 7 saatten fazla YouTube kullanmaktadırlar.

Tablo-3 Faktör analizi sonuçları

\begin{tabular}{|c|c|c|c|c|c|c|c|}
\hline FAKTÖR & \multirow[t]{2}{*}{ MADDELER } & \multicolumn{5}{|c|}{ Faktör Yapısı } & \multirow{2}{*}{$\begin{array}{l}\text { Cronbach } \\
\text { Alpha }\end{array}$} \\
\hline \multirow{6}{*}{$\begin{array}{c}\text { Satın Alma } \\
\text { Davranışı }\end{array}$} & & 1 & 2 & 3 & 4 & 5 & \\
\hline & $\begin{array}{l}\text { M.14YouTube'da reklamlarını } \\
\text { gördügüüm ürün veya hizmetleri } \\
\text { satın almak isterim. }\end{array}$ & 870 & & & & & \multirow[t]{5}{*}{,909 } \\
\hline & $\begin{array}{l}\text { M.15YouTube'da reklamlarını } \\
\text { gördügüüm ürün veya hizmetleri } \\
\text { satın alırım. }\end{array}$ & ,845 & & & & & \\
\hline & $\begin{array}{l}\text { M.16YouTube' da reklamlarını } \\
\text { gördüğüm ürün veya hizmetleri } \\
\text { arkadaşlarıma tavsiye ederim. }\end{array}$ &, 780 & & & & & \\
\hline & $\begin{array}{l}\text { M.17YouTube'da yayınlanan } \\
\text { reklamlar bende merak } \\
\text { uyandırır. }\end{array}$ & ,672 & & & & & \\
\hline & $\begin{array}{l}\text { M.13YouTube'da gördüğüum } \\
\text { reklamların içeriğine bakarım }\end{array}$ & ,669 & & & & & \\
\hline \multirow[t]{4}{*}{ Eğlence } & $\begin{array}{l}\text { M.4YouTube reklamları } \\
\text { eğlencelidir. }\end{array}$ & & ,840 & & & & \multirow[t]{4}{*}{,932 } \\
\hline & $\begin{array}{l}\text { M.5YouTube reklamlar1 } \\
\text { zevklidir. }\end{array}$ & & ,817 & & & & \\
\hline & $\begin{array}{l}\text { M.7YouTube reklamları ilgi } \\
\text { çekicidir. }\end{array}$ & &, 717 & & & & \\
\hline & $\begin{array}{l}\text { M.6YouTube reklamları } \\
\text { memnuniyet vericidir. }\end{array}$ & & ,673 & & & & \\
\hline \multirow[t]{3}{*}{ Bilgi vericilik } & $\begin{array}{l}\text { M.2YouTube reklamları, ürün } \\
\text { veya hizmetlerle ilgili bilgiler } \\
\text { sağlamaktadır }\end{array}$ & & & ,854 & & & \multirow[t]{3}{*}{,840 } \\
\hline & $\begin{array}{l}\text { M.3 YouTube reklamları, ürün } \\
\text { veya hizmetlerle ilgili güncel } \\
\text { bilgiler sunmaktadır. }\end{array}$ & & & ,769 & & & \\
\hline & $\begin{array}{l}\text { M.1YouTube reklamları ürün } \\
\text { veya hizmet bilgisi için iyi bir } \\
\text { kaynaktır }\end{array}$ & & & ,719 & & & \\
\hline \multirow[t]{3}{*}{ Güvenilirlik } & $\begin{array}{l}\text { M.9YouTube reklamları } \\
\text { güvenilirdir }\end{array}$ & & & &, 848 & & \multirow[t]{3}{*}{,879 } \\
\hline & $\begin{array}{l}\text { M.8YouTube reklamları } \\
\text { inandırıcidır }\end{array}$ & & & &, 745 & & \\
\hline & $\begin{array}{l}\text { M.10YouTube reklamları akla } \\
\text { yatkındır. }\end{array}$ & & & &, 739 & & \\
\hline
\end{tabular}




\begin{tabular}{|c|c|c|c|c|c|c|c|}
\hline \multirow[t]{8}{*}{$\begin{array}{l}\text { Rahatsız } \\
\text { Edicilik }\end{array}$} & $\begin{array}{l}\text { M.11YouTube reklamları sinir } \\
\text { bozucudur. }\end{array}$ & & & & & ,894 & \multirow[t]{8}{*}{892} \\
\hline & $\begin{array}{l}\text { M.12YouTube reklamlar1 } \\
\text { rahatsı edicidir }\end{array}$ & & & & & ,873 & \\
\hline & Özdeğer & 3,708 & 3,140 & 2,489 & 2,386 & 1,982 & \\
\hline & Açıklanan Varyans & 21,814 & 18,472 & 14,643 & 14,033 & 11,660 & \\
\hline & Toplam Açılanan Varyans & \multicolumn{5}{|c|}{80,622} & \\
\hline & KMO & \multicolumn{5}{|c|}{,925 } & \\
\hline & Barlett's Testi & \multicolumn{5}{|c|}{$7503,086$ (sd. 136; $p=, 000)$} & \\
\hline & Cronbach Alpha & \multicolumn{5}{|c|}{,884 } & \\
\hline
\end{tabular}

Araştırmada verilerin faktör analizine uygunluğu ve örneklem yeterliliği için KaiserMeyer-Olkin (KMO) testi ve Barlett-küresellik testi uygulanmıştır. Bu araştırmada ortaya çıkan KMO değeri: ,925 olduğundan faktör analizi için örneklem yeterliliğinin mükemmel (Durmuş, Yurtkoru, \& Çinko, 2013, s. 80) olduğu söylenebilir. Barlett küresellik testi sonuçlarına göre ise ki kare (sd. 136=7503,086; p<.01) değeri anlamlıdır. Cronbch's Alpha değeri, 884 olduğundan verilerin güvenilirliğinin yüksek derecede olduğu söylenebilir (Akgül \& Çevik, 2005, s. 436). Faktör analizinde faktör yükü 0.60 kriteri kullanılmıştır. Faktör analizinde, herhangi bir maddenin istenilen faktör ağırlığına sahip olmadığı durumlarda maddenin analiz dışı bırakılması gerekir (Durmuş, Yurtkoru, \& Çinko, 2013, s. 85). Bu araştırmadaki faktör analizi sonucunda herhangi bir maddenin istenilen faktör ağırlığı altında olmadığı için anket formundaki hiçbir madde analizi dışı bırakılmamıştır. Böylece faktör analizine anket formundaki 17 madde ile devam edilmiş ve Varimax rotasyonu uygulanmıştır. Analiz sonucunda 17 madde ile öz değeri 1'den büyük olan beş faktör (Satın Alma Davranış1, Eğlence, Bilgi vericilik, Güvenilirlik ve Rahatsız Edicilik) elde edilmiştir. Bu beş faktörün açıkladıkları toplam varyans \%80,622'dir. Açıklanan varyans oranının \%60'dan az olmaması beklenir. Kimi araştırmacılar ise bu oranın en az \%50 olması gerektiğini ifade etmektedirler (Altunışık, Çoşkun, Bayraktaroğlu, \& Yıldırım, 2010, s. 273).

Toplam varyansın \%21,814'ünü açıklayan birinci faktör olan "Satın Alma Davranışı”" faktörünün Cronbach Alfa katsayısı $\alpha=, 909$ olduğundan yüksek derecede güvenilir olduğu söylenebilir. Faktörün öz değeri (3,708)'dir. "YouTube'da reklamlarını gördüğüm ürün veya hizmetleri satın almak isterim" maddesinin faktör yükü $(, 870)^{\prime}$ tir ve en yüksek faktör yüklü maddedir. En düşük yüke sahip olan madde ise; "YouTube'da gördüğüm reklamların içeriğine bakarım" (,669) maddesidir.

Araştırmada ikinci faktör "Eğlence" olarak tanımlanmıştır. Toplam varyansın \%18,472'sinin açıklandığı eğlence faktörünün öz değeri 3,140 ve faktör güvenilirliği ise 
$\alpha=, 932$ 'dir. Bu oran ile eğlence faktörü tüm faktörler arasındaki en yüksek güvenilirliğe sahip olan faktördür. "YouTube reklamları eğlencelidir" maddesi $(, 840)$ ile en yüksek faktör yüklü maddedir. En düşük faktör yüküne sahip olan madde "YouTube reklamları memnuniyet vericidir" (,673) maddesidir.

Araştırmada üçüncü faktör olarak tanımlanan "Bilgi vericilik" faktörünün toplam varyansı açıklama oranı \%14,643'tür. Bilgi vericilik faktörü toplam varyansın \%14,643'ünü açıklamaktadır. Bilgi vericilik faktörünün öz değeri 2,489, Cronbach Alfa katsayısı ise $\alpha=, 840$ 'tır. Buna göre bilgi vericilik faktörü yüksek derecede güvenilirdir. "YouTube reklamları, ürün veya hizmetlerle ilgili bilgiler sağlamaktadır” maddesinin faktör yükü (,854)'tür ve bu faktördeki en yüksek faktör yüklü maddedir. "YouTube reklamları ürün veya hizmet bilgisi için iyi bir kaynaktır” (,719) maddesi bu faktördeki en düşük yüklü maddedir.

Araştırmada tanımlanan dördüncü faktör “Güvenilirlik” faktörüdür ve toplam varyansın \%14,033'ünü açıklamaktadır. Faktörün öz değeri 2,386 ve güvenilirlik katsayısı $\alpha=, 879$ 'dur. Böylece bu faktör yüksek derecede güvenilirdir. "YouTube reklamları güvenilirdir" maddesinin faktör yükü (,848)' dir ve bu faktördeki en yüksek yük değerini alan maddedir. En düşük faktör yüküne sahip olan madde ise "YouTube reklamları akla yatkındır" $(, 739)$ maddesidir.

"Rahatsız Edicilik” faktörü araştırmada tanımlanan beşinci faktördür. Rahatsız edicilik faktörü toplam varyansın 11,660’ını açıklamaktadır. Faktörün öz değeri 1,982, güvenilirlik katsayısı ise $\alpha=, 892$ ' dir ve buna göre faktör yüksek derecede güvenilirdir. "YouTube reklamları sinir bozucudur" maddesinin faktör yükü $(, 894)$ iken, "YouTube reklamları rahatsız edicidir" maddesini yükü $(, 873)$ 'dür. 
Tablo-4 Faktörlere ait ifadelerin tanımlayıcı istatistikleri $(n=546)$

\begin{tabular}{|c|c|c|c|c|}
\hline \multirow[t]{6}{*}{$\begin{array}{l}\text { Satın Alma } \\
\text { Davranışı }\end{array}$} & MADDELER & $\overline{\bar{X}}$ & S.D & $\begin{array}{c}\text { Faktör } \\
\text { Ort. } \\
(\bar{X})\end{array}$ \\
\hline & $\begin{array}{l}\text { S.14YouTube'da reklamlarını gördüğüm ürün veya hizmetleri satın } \\
\text { almak isterim. }\end{array}$ & 2,06 & 979 & \multirow{5}{*}{2,11} \\
\hline & $\begin{array}{l}\text { S.15YouTube'da reklamlarını gördüğüm ürün veya hizmetleri satın } \\
\text { alırım. }\end{array}$ & 1,95 & 940 & \\
\hline & $\begin{array}{l}\text { S.16YouTube'da reklamlarını gördüğüm ürün veya hizmetleri } \\
\text { arkadaşlarıma tavsiye ederim. }\end{array}$ & 1,98 & ,993 & \\
\hline & S.17YouTube'da yayınlanan reklamlar bende merak uyandırır. & 2,32 & 1,167 & \\
\hline & S.13YouTube'da gördüğüm reklamların içeriğine bakarım & 2,28 & 1,149 & \\
\hline \multirow[t]{4}{*}{ Ĕ̆lence } & S.4YouTube reklamları eğlencelidir. & 2,33 & 1,109 & \multirow{4}{*}{2,29} \\
\hline & S.5YouTube reklamları zevklidir. & 2,27 & 1,087 & \\
\hline & S.7YouTube reklamları ilgi çekicidir. & 2,40 & 1,152 & \\
\hline & S.6YouTube reklamları memnuniyet vericidir & 2,17 & 1,067 & \\
\hline \multirow[t]{3}{*}{ Bilgi vericilik } & $\begin{array}{l}\text { S.2YouTube reklamları, ürün veya hizmetlerle ilgili bilgiler } \\
\text { sağlamaktadır }\end{array}$ & 3,18 & 1,181 & \multirow{3}{*}{3,15} \\
\hline & $\begin{array}{l}\text { S.3YouTube reklamları, ürün veya hizmetlerle ilgili güncel bilgiler } \\
\text { sunmaktadır. }\end{array}$ & 3,38 & 1,108 & \\
\hline & S.1YouTube reklamları ürün veya hizmet bilgisi için iyi bir kaynaktır & 2,89 & 1,219 & \\
\hline \multirow[t]{3}{*}{ Güvenilirlik } & S.9YouTube reklamları güvenilirdir & 2,49 & 1,028 & \multirow{3}{*}{2,48} \\
\hline & S.8YouTube reklamları inandırıcıdır & 2,39 & 1,018 & \\
\hline & S.10YouTube reklamları akla yatkındır. & 2,58 & 1,052 & \\
\hline \multirow{2}{*}{$\begin{array}{l}\text { Rahatsiz } \\
\text { Edicilik }\end{array}$} & S.11YouTube reklamları sinir bozucudur. & 3,85 & 1,211 & \multirow[t]{2}{*}{3,82} \\
\hline & S.12YouTube reklamları rahatsı edicidir & 3,79 & 1,149 & \\
\hline
\end{tabular}

Tablo-4'te faktörlere ait maddelerin tanımlayıcı istatistiklerine yer verilmektedir. En yüksek ortalamaya sahip faktör rahatsız edicilik faktörüdür $(\bar{X}=3,82)$. Bu sonuca göre araştırmaya katılanların YouTube reklamlarından rahatsız oldukları söylenebilir. İkinci sıradaki önem verilen faktör ise bilgi vericilik faktörüdür ( $\bar{X}=3,15)$. Tablo-4'e göre, en düşük ortalamaya sahip olan faktör satın alma davranışı faktörüdür $(\bar{X}=2,11)$. 
Tablo-5 Faktörler arası korelasyon analizi

\begin{tabular}{|c|c|c|c|c|c|c|}
\hline & & $\begin{array}{c}\text { Satın Alma } \\
\text { Davranışı }\end{array}$ & Eğlence & Bilgi vericilik & Güvenilirlik & $\begin{array}{l}\text { Rahatsız } \\
\text { Edicilik }\end{array}$ \\
\hline Satın Alma & $\mathrm{r}$ & 1 & ,680** & ,539** & ,604** &,- 465 *** \\
\hline \multirow[t]{2}{*}{ Davranışı } & $\mathrm{p}$ & &, 000 &, 000 & ,000 &, 000 \\
\hline & $\mathrm{N}$ & 546 & 546 & 546 & 546 & 546 \\
\hline \multirow[t]{3}{*}{ Eğlence } & $\mathrm{r}$ & & 1 & ,625** & ,638** &,- 546 ** \\
\hline & $\mathrm{p}$ & & &, 000 &, 000 &, 000 \\
\hline & $\mathrm{N}$ & & 546 & 546 & 546 & 546 \\
\hline \multirow[t]{3}{*}{ Bilgi vericilik } & $\mathrm{r}$ & & & 1 & ,598** &,- 350 ** \\
\hline & $\mathrm{p}$ & & & & ,000 & ,000 \\
\hline & $\mathrm{N}$ & & & 546 & 546 & 546 \\
\hline \multirow[t]{3}{*}{ Güvenilirlik } & $r$ & & & & 1 &,- 413 ** \\
\hline & $\mathrm{p}$ & & & & &, 000 \\
\hline & $\mathrm{N}$ & & & & 546 & 546 \\
\hline \multirow[t]{3}{*}{ Rahatsız Edicilik } & $\mathrm{r}$ & & & & & 1 \\
\hline & $\mathrm{p}$ & & & & & \\
\hline & $\mathrm{N}$ & & & & & 546 \\
\hline
\end{tabular}

Tablo-5’te faktörler arası korelasyon analizi sonuçları görülmektedir. Tablo 5.'e göre satın alma davranışı faktörü ile eğlence $(r=, 680)$, bilgi vericilik $(r=, 539)$ ve güvenilirlik $(r=604)$ faktörleri arasında anlamlı $(\mathrm{p}=, 000)$ pozitif yönde ve orta düzeyde bir ilişki bulunmaktadır. Diğer bir ifade ile araştırmaya katılanların YouTube reklamlarını eğlendirici, bilgilendirici ve güvenilir buldukça ve bu tutumları olumlu yönde arttıkça, reklamlarda yer alan ürün ve hizmete yönelik satın alma davranışına yönelik tutumları da olumlu yönde artabileceği söylenebilir. Satın alma davranışına yönelik en güçlü ilişkinin eğlence faktöründe olduğu görülmektedir. Öte yandan rahatsız edicilik faktörü ile satın alma davranışı arasında ise anlamlı ancak negatif yönde ve düşük düzeyde bir ilişki bulunmaktadır $(r=-465 ; p=, 000)$.

Tüketicilerin YouTube reklamlarına ilișkin tutumlarını belirlemek için kullanılan ölçekten elde edilen faktörlerin (Eğlence, Bilgi vericilik, Güvenilirlik ve Rahatsız Edicilik) satın alma davranışına etkisine ve ilişkisine yönelik çoklu regresyon analizi bulguları Tablo6'da gösterilmektedir. 
Tablo-6 Çoklu regresyon analizi bulguları

\begin{tabular}{|c|c|c|c|c|c|c|}
\hline Bağımlı Değişken & Bağımsız Değişken & $\begin{array}{c}\text { Standardize Edilmiş } \\
\text { Katsayıllar } \\
\text { Beta }\end{array}$ & $\mathrm{t}$ & $\mathbf{p}$ & $\begin{array}{c}\text { Standart } \\
\text { Hata }\end{array}$ & VIF \\
\hline \multirow{4}{*}{ Satın Alma Davranışı } & Eğlence &, 402 & 8,868 &, 000 &, 040 & 2,341 \\
\hline & Bilgi vericilik &, 106 & 2,641 &, 008 &, 035 & 1,844 \\
\hline & Güvenilirlik & ,239 & 5,845 &, 000 & ,040 & 1,914 \\
\hline & Rahatsız Edicilik &,- 109 & $-3,079$ &, 002 &, 028 & 1,440 \\
\hline $\mathbf{R}^{2}$ & \multicolumn{5}{|c|}{, 526} & \\
\hline Düzeltilmiş $\mathbf{R}^{2}$ & \multicolumn{5}{|c|}{, 522} & \\
\hline F İstatistiği & \multicolumn{5}{|c|}{150,$050 ; p=, 000$} & \\
\hline
\end{tabular}

Tablo-6'ya bakıldığında oluşturulan regresyon modelinin istatistiksel olarak anlamlı olduğu görülmektedir ( F: 150,050; p=,000). Çoklu regresyon analizi sonucu elde edilen değerler incelendiğinde tüm bağımsız değişkenler için p değerleri 0,05 'ten küçük olduğundan, YouTube reklamlarına yönelik tutumlarla (Eğlence, Bilgi vericilik, Güvenilirlik ve Rahatsız Edicilik) "Satın Alma Davranışı” değişkenini açıklamak istatistiksel olarak anlamlıdır. Bunun yanında VIF (Varyans Büyütme Faktörü) değerlerinin 10'dan küçük olması değişkenler arası çoklu bağlantı sorunu olmadığına işaret etmektedir (Durmuş, Yurtkoru, \& Çinko, 2013, s. 156). Modelin açıklayıcı gücünü gösteren $\mathrm{R}^{2}$ değeri =,526 olarak bulunmuştur. Diğer bir ifade ile eğlence, bilgi vericilik, güvenilirlik ve rahatsız edicilik bağımsız değişkenlerinin bağımlı değişken olan satın alma davranışını \%52,6 oranında ve 0,01 anlamlılık düzeyinde açıkladığ bu araştırmada tespit edilmiştir. Ayrıca; eğlence, bilgi vericilik, güvenilirlik ve rahatsız edicilik değişkenleri ile satın alma davranışı arasında orta düzeyde ve anlamlı bir ilişki bulunmaktadır.

Katsayılar tablosu incelendiğinde; tüketicilerin satın alma davranışı üzerinde en çok etkiyi sağlayan tutumun eğlence faktörü olduğu görülmektedir $(\beta=, 402)$. İkinci düzeyde etkiye sahip olan faktör güvenilirliktir $(\beta=, 239)$. Üçüncü düzeyde etkiye sahip olan faktör ise bilgi vericilik faktörüdür $(\beta=, 106)$. Diğer yandan rahatsız edicilik faktörü ile satın alma davranışı faktörü arasında etki düzeyi negatif yöndedir $(\beta=-, 109)$. Tüm bu sonuçlar değerlendirildiğinde;

$\mathbf{H}_{1}, \mathbf{H}_{2}, \mathbf{H}_{3}$ ve $\mathbf{H}_{4}$ hipotezleri desteklenmiştir.

Tablo-7 Gelir durumu ile faktörler arasındaki korelasyon analizi sonuçları

\begin{tabular}{|c|c|c|c|c|c|c|}
\hline & & $\begin{array}{c}\text { Satın Alma } \\
\text { Davranışı }\end{array}$ & Eğlence & Bilgi vericilik & Güvenilirlik & $\begin{array}{c}\text { Rahatsız } \\
\text { Edicilik } \\
\end{array}$ \\
\hline \multirow[t]{3}{*}{ Gelir } & $\mathrm{r}$ &, 072 & $142 * *$ & ,030 & ,063 &,$- 124 * *$ \\
\hline & $\mathrm{p}$ & ,095 & ,001 & ,481 &, 141 & ,004 \\
\hline & $\mathrm{N}$ & 546 & 546 & 546 & 546 & 546 \\
\hline
\end{tabular}


Araştırmaya katılanların gelir durumu ile faktörler arasındaki ilişki analiz edildiğinde (Tablo-7), gelir ve eğlence faktörü arasında anlamlı, pozitif ve düşük düzeyde bir ilişki görülmüştür. Böylece kişilerin gelirleri arttıkça düşük düzeyde de olsa YouTube reklamlarını nispeten daha eğlenceli buldukları söylenebilir. Öte yandan gelir durumu ile rahatsız edicilik faktörü arasında anlamlı, negatif ve düşük düzeyde bir ilişski tespit edilmiştir. Buna göre, kişilerin gelirleri arttıkça YouTube reklamlarına yönelik rahatsız edicilik boyutunda nispeten bir azalma görülmektedir. Bu sonuca göre $\mathbf{H}_{5}$ hipotezi de desteklenmiştir.

Son olarak araştırmaya katılanların cinsiyet değişkeni ile YouTube reklamlarına yönelik tutumlara etki eden faktörler arasında anlamlı bir farklılık olup olmadığını analiz etmek için Bağımsız Örneklem T-Testi yapılmıştır. Cinsiyet ile YouTube reklamlarına etki eden faktörler arasında istatistiksel olarak anlamlı bir farklılık görülmemiştir. Böylece $\mathbf{H}_{6}$ hipotezi desteklenmemiştir.

\section{SONUÇ VE TARTIŞMA}

Bu çalışmada, YouTube'da yayınlanan reklamlara yönelik tüketici tutumlarını etkileyen faktörlerin satın alma davranışı üzerine olan etkisinin tespiti amaçlanmıştır. Yapılan faktör analizi sonucunda satın alma davranışına etki eden dört faktör (Eğlence, Bilgi Vericilik, Güvenilirlik ve Rahatsız edicilik) elde edilmiştir. Satın alma davranışı da ayrı bir faktör olarak ele alınmıştır. En yüksek ortalamaya sahip faktör "Rahatsız Edicilik”tir. Buna göre araştırmaya katılanların YouTube reklamlarından rahatsız oldukları söylenebilir. Bu faktörü sırasıyla, bilgi vericilik, güvenilirlik ve eğlence takip etmektedir.

Bu çalışmada, araştırmaya katılanların YouTube reklamlarını eğlendirici, bilgilendirici ve güvenilir buldukça ve bu tutumları olumlu yönde arttıkça, reklamlarda yer alan ürün ve hizmete yönelik satın alma davranışına yönelik tutumları da olumlu yönde artabileceği söylenebilir. Satın alma davranışına yönelik en güçlü ilişkinin eğlence faktöründe olduğu görülmektedir. Öte yandan rahatsız edicilik faktörü ile satın alma davranışı arasında ise negatif yönde bir ilişki bulunmaktadır. Bu sonuca göre, YouTube reklamlarındaki rahatsız edicilik azaldıkça satın alma davranışına yönelik olumlu tutum artabilecektir. Elde edilen bu sonuçlar, literatürdeki benzer çalışmalar (Aziza \& Astuti, 2019; Dehghani, Niaki, Ramezani, \& Sali, 2016; Haida \& Rahim, 2015) ile de desteklenmektedir. Aziza \& Astuti (2019), yaptıkları 
araştırmada YouTube reklamlarının eğlenceli ve bilgilendirici olmasının reklam değeri üzerinde olumlu bir etkisi olduğu sonucuna ulaşmışlardır. Başka bir bir ifade ile YouTube reklamları ne kadar eğlenceli ve bilgilendirici olursa reklama verilen verilen değer de o kadar yüksek olabilmektedir. Aynı araştırmada reklamdaki rahatsız ediciliğin olumsuz tutumlara neden olabileceği vurgulanmaktadır. Deghani ve diğerlerinin (2016) yaptığı araştırmada, eğlence, bilgi vericilik, güvenilirlik ve rahatsız edicilik faktörlerinin satın alma davranışı üzerinde doğrudan ve anlamlı bir etkisini olduğu görülmektedir. Haida ve Rahim (2015) ise gerçekleştirmiş oldukları araştırmada, sosyal medya reklamlarında olumsuz tutumların önüne geçebilmek için kullanıcıları rahatsız eden uygulamalara yer verilmemesi gerektiğini belirtmişlerdir. Böylece reklamlara yönelik olumlu tutumların artması, markanın farkındalığını arttırabilecek ve tüketicinin satın alma niyetine de yol açabilecektir. Sonuç olarak tüketicilerde reklamlara yönelik olumlu bir tutum oluştuğunda, davranışsal olarak da olumlu bir tutum sergilenmektedir.

$\mathrm{Bu}$ araştırmada, tüketicilerin satın alma davranışı üzerinde en çok etkiyi sağlayan tutumun eğlence faktörü olduğu sonucuna ulaşılmıştır. Eğlence, bilgi vericilik ve güvenilirlik faktörleri tüketicilerin satın alma davranışını olumlu yönde etkiliyorken, rahatsız edicilik faktörü ise olumsuz (negatif) yönde etkilemektedir. Elde edilen bu sonuçların literatürdeki benzer çalışmalarla da (Akkaya, Akyol, \& Şimşek, 2017; Dehghani, Niaki, Ramezani, \& Sali, 2016; Nabila \& Achyar, 2019; Yoldaş \& Özaydın, 2017) uyumlu olduğu söylenebilir. Akkaya, Akyol ve Şimşek (2017), bilgi vericilik ve eğlence faktörlerinin sosyal medya reklamlarına yönelik tutumun satın alma davranışını ve satın alma niyetini pozitif yönde etkilediği sonucuna yaptıkları araştırmada ulaşmışlardır. Dehghani, Niaki, Ramezani, ve Sali yaptıkları araştırmada (2016), rahatsız edicilik faktörünün YouTube reklamlarına yönelik tutumda olumsuz bir etkiye sahip olduğunu göstermişlerdir. Öte yandan aynı araştırmada YouTube reklamlarının tüketicilerin satın alma niyeti üzerinde önemli etkileri olduğu sonucuna da ulaşmışlardır. Nabila ve Achyar (2019) gerçekleştirdikleri araştırmada ise, eğlence ve güvenilirlik faktörlerinin satın alma niyetini olumlu yönde etkilediğini ortaya koymuşlardır. Ayrıca bu araştırmada, rahatsız edicilik unsurunun YouTube reklamlarına yönelik olumsuz bir tutum olduğu görülmüştür. Son olarak Yoldaş ve Özaydın (2017) üniversite öğrencilerine yönelik gerçekleştirmiş oldukları araştırmada, sosyal medya reklamlarının bilgilendirme, eğlence ve güvenilirlik boyutlarının tüketicilerin satın alma niyetini olumlu yönde etkilediği, rahatsız edicilik boyutunun ise 
olumsuz yönde etkildeğini sonucu ortaya çıkmıştır. Ayrıca eğlence boyutunun diğer faktörlere göre tüketicilerin satın alma niyetinin daha fazla etkilemektedir.

Çalışmada demografik değişkenlerden cinsiyet ve gelir değişkenleri ile faktörler arasındaki ilişkiler de analiz edilmiştir. Araştırmaya katılanların cinsiyet durumları ile YouTube reklamlarına etki eden faktörler arasında anlamlı bir farklılık görülmemiştir. Gelir ile reklamlara yönelik tutumları etkileyen faktörler arasındaki ilişki analiz edildiğinde kişilerin gelirleri arttıkça düşük düzeyde de olsa YouTube reklamlarını nispeten daha eğlenceli buldukları söylenebilir. Öte yandan kişilerin gelirleri arttıkça YouTube reklamlarına yönelik rahatsız edicilik tutumu da nispeten azalma göstermektedir. Diğer bir ifade ile gelir durumu arttıkça YouTube reklamlarına yönelik olumlu tutumlar da artabilir. Bu sonuç Akar ve Topçu (2011) ve Koçer ve Koçkaya'nın (2016) çalışmaları ile benzerlik göstermektedir. Akar ve Topçu'nun (2011) yapmış olduğu araştırmaya göre; tüketicilerin sosyal medya pazarlamasına yönelik tutumlarında aile gelirleri açısından farklılıklar olduğu görülmüştür. Geliri düşük olan aileler ile geliri daha yüksek olan aileler arasında fark bulunmaktadır. Buna göre tüketicilerin gelir seviyeleri yükseldikçe, tüketicilerin sosyal medya pazarlamasına yönelik tutumları da olumlu yönde değişmektedir. Diğer bir araştırmaya göre ise (Koçer \& Koçkaya, 2016), tüketicilerin gelir durumu arttıkça sosyal medya reklamlarına yönelik tutumlarında da olumlu yönde bir artış meydana gelmektedir.

YouTube'da yayınlanan reklamlarda markaların eğlence ve güvenilirlik unsuruna daha fazla önem vermeleri ve tüketiciyi rahatsız edici unsurlardan kaçınmaları gerekmektedir. YouTube' da yayınlanan videoların başında veya ortasında yayınlanan reklamlardan tüketiciler rahatsız olmaktadır. Markalar tarafindan sosyal medya reklam aracı olarak tercih edilen YouTube'un bu rahatsız edicilik durumunu gözden geçirmesi gereklidir. Öte yandan YouTube reklamları tüketiciler tarafından bilgi kaynağı olarak da görülmektedir. Böylece bu platform üzerinden ürün ve hizmet tanıtımlarının yapılması önemlidir. YouTube reklamlarının tüketicilerin satın alma davranışına olumlu anlamda etki etmesinin neticesinde markaların tüketici tutumlarını bilmeleri ve reklam içeriklerini buna göre yapmaları reklamların etkisini arttırabilir.

$\mathrm{Bu}$ çalışma araştırmanın yapıldığı tarih ve örneklem ile sınırlıdır. İleriki çalışmalarda farklı örneklemlerle benzer sonuçların elde edilip edilmeyeceğinin araştırılması literatüre önemli katkılar sağlayacaktır. Ayrıca, bu araştırmada tüketici tutumlarına etki eden faktörler 
olarak analiz edilen bilgi vericilik, eğlence, güvenilirlik, rahatsız edicilik faktörleri dışındaki başka faktörlerin de ortaya konulması ve bunların satın alma davranışına etkisi araştırılabilir.

\section{EXTENDED ABSTRACT}

As the individuals pay no fee for social media usage, produce content easily, and transport their consuming habits on social media environments, social media platforms have turned into an advertising platform for corporations and brands. The main purpose of social media advertisements is that they focus on publicizing and selling. Through social media advertisements, brands can produce cost-efficient advertisement content, spread them quickly, and get access to targeted broad masses. Today, YouTube has a paramount position in social media advertising. Being the most used media instrument among social media platforms in Turkey, YouTube achieved to draw advertisers' attention in terms of brand communication and marketing owing to the rise of digital platforms, widespread use, and improvement of content advertisement.

Researches in the literature show that it is important to know consumers' attitudes towards advertisements in terms of their behavioral reactions and persuading them. Consumers' attitudes are important to know to determine the advertisement contents that will be produced. In literature, although there are some researches on the effect of attitudes towards social media advertisements on purchasing behavior, there are only a few researches carried out on the role of factors affecting consumers' attitudes towards YouTube advertisements on purchasing behavior. In this sense, it is important to examine how and in what way YouTube advertisements affect consumers' purchasing behavior

In this study, it is aimed to find out the effect of the factors influencing consumers' attitudes towards the advertisements aired on YouTube on purchasing behavior. Using a convenience sampling method, the data is collected via an online survey in which YouTube users ( $\mathrm{N}=546,50,4 \%$ female, 49,6\% male) living in Turkey attended. The survey form is carried out using the Google Documents website between the dates 25 July-9 August 2018 and is shared on social media platforms like Facebook, Twitter, LinkedIn and WhatsApp to collect the data from the YouTube users. The questionnaire is composed of two sections. In the first section, 17 items include factors affecting the advertisements and purchasing behavior variables. In the 
second section, there are questions that ask the participants' demographic features (Gender, Age, Educational Status) and their daily frequency of internet and YouTube usage. As a result of the data obtained from the survey, frequency analysis, factor analysis, multiple regression analysis, Pearson's correlation coefficient analyses, and independent sample T-Test analysis are carried out and the hypothesizes are tested.

According to the research findings, as long as YouTube advertisements are regarded as entertaining and credible, in other words, as long as the consumers' attitudes towards the advertisements are positive, their purchasing behavior for the product or service in the advertisement will be positive. The strongest correlation related to purchasing behavior is the entertainment factor. On the other hand, as long as the consumers' irritation attitudes towards YouTube advertisements decrease, their positive attitudes to purchasing behavior may increase.

It is found out that there is a significant effect of four factors (entertainment, informativeness, credibility, and irritation) that affect the consumers' attitudes towards YouTube advertisements on purchasing behavior. Informativeness, entertainment, and credibility factors positively affect the consumers' purchasing behavior, but the irritation factor affects the consumers' purchasing behavior negatively. If which of the factors affects the consumers' purchasing behavior most is examined, it is found out that the entertainment factor affects the purchasing behavior more than the other factors. On the other hand, this research shows that the credibility and reasonability of the contents of the advertisements may cause the consumers to watch the advertisements and make positive contribution to the purchasing behavior at the same time. As a result, when the consumers generate a positive attitude, they tend to show a positive attitude as a behavior.

In the research, the correlations between gender and income variables are analyzed as well. There is no statistical significance between the participants' gender and the factors. When the consumers' income level increases, it is found out in the research that they find YouTube advertisements relatively more entertaining. The brands must give more importance to entertainment and credibility factors in their YouTube advertisements and avoid irritating the consumers. The brands, which air their advertisements on YouTube, should know the consumers' attitudes and produce their advertisement content about this. These may increase the effectiveness of their advertisements. This study is limited to its sample and the dates on 
which the research is done. In future studies, studying in a broader sample to find similar results or not will make great contributions to the literature.

\section{KAYNAKÇA}

Akar, E., \& Topçu, B. (2011). An examination of the factors influencing consumers' attitudes toward social media marketing. Journal of Internet Commerce, 10(1), 35-67. doi:10.1080/15332861.2011.558456

Akgül, A., \& Çevik, O. (2005). İstatiksel analiz teknikleri "SPSS'te işletme yönetimi uygulamaları. Ankara: Emek Ofset.

Akkaya, D. T., Akyol, A., \& Şimşek, G. G. (2017). The effect of consumer perceptions on their attitude, behavior and purchase intention in social media advertising. Marmara Üniversitesi İktisadi ve İdari Bilimler Dergisi, 39(II), 361-388. doi:10.14780/muibbd.384073

Aktaş, H., \& Aktan, E. (2014). Sosyal medya reklamları ve tüketici tutumları: Bir reklam mecrası olarak Facebook. International Academic Conference- Dijital İletişim Etkisi, (s. 422-343). İstanbul.

Altunışık, R., Çoşkun, R., Bayraktaroğlu, S., \& Yıldırım, E. (2010). Sosyal bilimlerde araştırma yöntemleri SPSS uygulamaları. Sakarya: Sakarya Yayıncılık.

Aydın, G. (2016). Attitudes towards digital advertisiments: testing differences between social media ads and mobile ads. International Journal of Research in Business Studies and Management, 3(2), 1-11.

Aziza, D. N., \& Astuti, R. D. (2019). Evaluating the effect of YouTube advertising towards young costomers' purchase intention. Advences in Economics, Business and Management Research, 72, 93-98. doi:10.2991/icbmr-18.2019.16

Bauer, H. H., Barnes, S. J., Reichardt, T., \& Neumann, M. M. (2005). Driving consumer acceptance of mobile marketing: a theoretical framework and empirical study. Journal of Electronic Commerce Research, 6(3), 181-192. 
Brackett, L. K., \& Carr, B. N. (2001). Cyberspace advertising vs.other media: consumer vs. mature student attitudes. Journal of Advertising Research, 41(5), 23-32. doi:10.2501/JAR-41-5-23-32

Can, L., \& Kaya, N. (2016). Kullanımlar ve doyumlar yaklaşımı bağlamında sosyal medya reklamlarına yönelik tutumun satın alma niyetine etkisi. Balkan Sosyal Bilimler Dergisi, 5(10), 30-39.

Çağlıyan, V., Işıklar, Z. E., \& Hassan, S. A. (2016). Üniversite öğrencilerinin satın alma davranışlarında sosyal medya reklamlarının etkisi: Selçuk Üniversitesinde bir araştırma. Selçuk Üniversitesi Sosyal ve Teknik Araştırmalar Dergisi(11), 43-46.

Çakın, Ö. (2018). Sosyal medya reklamcılığı. Ö. Çakın içinde, Gelenekselden dijitale reklam mecraları açıkhavadan sanal gerçeklik uygulamalarına (s. 175-198). Konya: Literatürk Academia.

Çalıkuşu, F. (2009). İnternet reklam çeşitlerinin tüketici tutumları açısından karşılaştırılması. Öneri, 8(32), 203-215. doi:10.14783/maruoneri.696201

Çelebi, S. İ. (2015). How do motives affect attitudes and behaviors toward internet? Computers in Human Behaviour(51), 312-324. doi:10.1016/j.chb.2015.05.011

Dehghani, M., \& Tumer, M. (2015). A research on effectiveness of Facebook advertising on enhancing purchase intention of consumers. Computers In Human Behavior(49), 597600. doi:10.1016/j.chb.2015.03.051

Dehghani, M., Niaki, M. K., Ramezani, I., \& Sali, R. (2016). Evaluating the influence of YouTube advertising for attraction of young customers. Computers in Human Behavior(59), 165-171. doi:10.1016/j.chb.2016.01.037

Ducoffe, R. (1996). Advertising value and advertising on the web. Journal of Advertising, 36(5), 21-35.

Durmuş, B., Yurtkoru, E. S., \& Çinko, M. (2013). Sosyal bilimlerde SPSS'le veri analizi. İstanbul: Beta Yayınları.

Elden, M. (2009). Reklam ve Reklamcılık. İstanbul: Say Yayınları.

Elden, M., Ulukök, Ö., \& Yeygel, S. (2005). Şimdi reklamlar. İstanbul: İletişim Yayınları. 
Hacıefendioğlu, Ş. (2011). Reklam ortamı olarak sosyal paylaşım siteleri ve bir araştırma. Bilgi ve Ekonomisi ve Yönetim Dergisi, VI(1), 107-115.

Haida, A., \& Rahim, H. L. (2015). Social media advertising value: a study on consumer's perception. International Academic Research Journal of Business and Technology, 1(1), $1-8$.

İnce, M., \& Bozyiğit, S. (2018). Tüketicilerin Instagram reklamlarına karşı tutumlarının satın alma davranışları üzerindeki etkisi: y ve z kuşağı üzerine bir araştırma. Beykoz Akademi Dergisi, 6(2), 39-56. doi:10.14514/BYK.m.26515393.2018.6/2

Karadeniz, M., \& Kocamaz, İ. (2019). The effect of Facebook, YouTube and Instagram Advertisements on consumers' buying behaviours. Turkish Journal of Marketing, 4(3), 298-311. doi:10.30685/tujom.v4i3.69

Kayapınar, Ö., Kayapınar, P. Y., \& Tan, Ö. (2017). Sosyal medya reklamlarına yönelik tüketici algıları ile e-sadakat arasındaki ilişkide markaya yönelik tutumun rolü. İşletme Araştırmaları Dergisi, 9(4), 472-494. doi:10.20491/isarder.2017.342

Kazançoğlu, İ., Üstündağlı, E., \& Baybars, M. (2012). Tüketicilerin sosyal ağ sitelerindeki reklamlara yönelik tutumlarının satınalma davranışları üzerinde etkisi: Facebook örneği. International Journal of Economics and Administrative Studies(8), 159-182.

Kırık, A. M. (2017). Sosyal medya ve internet ortamında viral reklamcılık. Konya: Çizgi Kitabevi.

Koçer, L. B., \& Koçkaya, F. A. (2016). Tüketicilerin sosyal medya rekamlarına yönelik tutum ve düşüncelerinin satın alma davranışlarına etkisi. Uluslararası Sosyal Araştırmalar Dergisi, 9(43), 2052-2062.

Kotler, P. (2000). Marketing management: Millennium Edition. New Jersey: Prentice-Hall.

Lee, J., \& Hong, I. B. (2016). Predicting positive user responses to social media advertising: the roles of emotional appeal, informativeness and creativity. International Journal of Information Management, 36(3), 360-373. doi:10.1016/j.ijinfomgt.2016.01.001

Lin, C. A., \& Kim, T. (2016). Predicting user response to sponsored advertising on social media via the technology acceptance model. Computers in Human Behavior(64), 710-718. doi:10.1016/j.chb.2016.07.027 
MacKenzie, S. B., \& Lutz, R. J. (1989). An empirical examination of the structural antecedents of attitude toward the an in an advertising pretesting context. Journal of Marketing, 53, 48-65.

MacKenzie, S. B., Lutz, R. J., \& Belch, G. E. (1986). The role of attitude toward the ad as a mediator of advertising effectiveness: a test of competing Explanations. Journal of Marketing Research, 23(2), 130-143.

Myfield, A. (2007). What is Social Media. https://www.icrossing.com/: https://www.icrossing.com/uk/sites/default/files_uk/insight_pdf_files/What\%20is\%20 Social\%20Media_iCrossing_ebook.pdf. adresinden alınd1

Nabila, S., \& Achyar, A. (2019). Analysis of factors affecting users' attitude toward the YouTube ads and their effects on purchase intention. Jurnal Manajemen dan Bisnis Sriwijaya, 17(2), 91-100. doi:10.29259/jmbs.v17i1.8858

Nurluoğlu, G. (2020). 15 maddede Türkiye'nin dijital tablosu: We Are Social 2020 Türkiye Raporu! https://medium.com/@gamzenurluoglu/15-maddede-t\%C3\%BCrkiyenindijital-tablosu-we-are-social-2020-t\%C3\%BCrkiye-raporu- adresinden alınd1

Odabaşı, Y., \& Barış, G. (2002). Tüketici Davranışı. İstanbul: MediaCat Kitapları.

Onay, A. (2012). Reklamlara yönelik tutumlar: nitel bir araştırma. Gümüşhane Üniversitesi İletişim Fakültesi Elektronik Dergisi, 1(4), 51-66.

Özkaşıkçı, I. (2012). Sosyal medya pazarla (ma). yeni çağda sosyal medya kullanımı ve performans ölçümü. İstanbul: Le Color/ Levent Print City.

Sabuncuoğlu, A., \& Gülay, G. (2016). Sosyal medyada görsel paylaşımından reklamcılığa: Instagram reklamlarının genç kullanıcılar üzerine etkisine dair bir araştırma. Gümüşhane Üniversitesi Sosyal Bilimler Enstitüsü Elektronik Dergisi, 7(15), 107-131. doi:10.17823/gusb.274.

Tabachnick, B. G., \& Fidell, L. S. (2007). Using multivariate Statistics. Boston: MA, Allyn \& Bacon/ Pearson Education.

Torun, E. (2017). Tüketici satın alma davranışları üzerinde internet ve sosyal medyanın yeri ve önemi. Elektronik Sosyal Bilimler Dergisi, 16(62), 955-970. 
Tuten, T. L. (2008). Advertising 2.0., Social Media Marketing in a Web 2.0 World. Westport: Praeger.

Wang, Y., Sun, S., Lei, W., \& Toncar, M. (2009). Examining beliefs and attitudes toward online advertising among Chinese consumers. Direct Marketing: An International Journal, 3(1), 52-66. doi:10.1108/17505930910945732

Yang, K. C., Huang, C. H., Yang, C., \& Yang, S. Y. (2017). Consumer attitudes toward online video advertisement: YouTube as a platform. Kybernetes, 46(5), 840-853. doi:10.1108/K-03-2016-0038

Yoldaş, M. A., \& Özaydın, H. (2017). Sosyal medya üzerinden yapılan reklamların satın alma davranışı üzerindeki etkisini belirlemeye yönelik bir uygulama. Avrasya Sosyal ve Ekonomi Araştırmaları Dergii, 4(12), 781-794.

Yüksel, O. (2020). Tüm boyutlarıyla dijital pazarlama ve sosyal medya. Ankara: Medya Akademi Yayınları.

Yükselen, C. (2016). Pazarlama ilkeler-yönetim-örnek olaylar. Ankara: Detay Yayıncıllk. 